\section{Regards sur l'économie allemande}

Bulletin économique du CIRAC

$71 \mid 2005$

Varia

\title{
Secteur caritatif
}

DZI-Spendenalmanach 2004/5 / ENSTE Dominik H., Die

Wohlfahrtsverbände in Deutschland. Eine ordnungspolitische Analyse und Reformagenda

\section{(2) OpenEdition}

12 Journals

Édition électronique

URL : http://journals.openedition.org/rea/400

DOI : $10.4000 /$ rea. 400

ISBN : 978-2-8218-0838-6

ISSN : 1965-0787

Éditeur

CIRAC

Édition imprimée

Date de publication : 1 mai 2005

ISSN : 1156-8992

Référence électronique

"Secteur caritatif », Regards sur l'économie allemande [En ligne], 71 | mai 2005, document 8, mis en ligne le 24 avril 2008, consulté le 22 septembre 2020. URL : http://journals.openedition.org/rea/400 ; DOI : https://doi.org/10.4000/rea.400

Ce document a été généré automatiquement le 22 septembre 2020.

(c) CIRAC 


\section{Secteur caritatif}

DZI-Spendenalmanach 2004/5 / ENSTE Dominik H., Die Wohlfahrtsverbände in Deutschland. Eine ordnungspolitische Analyse und Reformagenda

\section{RÉFÉRENCE}

DZI-Spendenalmanach 2004/5, Deutsches Zentralinstitut für Soziale Fragen , Berlin, 2004, $292 \mathrm{p}$.

ENSTE Dominik H., Die Wohlfahrtsverbände in Deutschland. Eine

ordnungspolitische Analyse und Reformagenda, IW-Analysen, Deutscher InstitutsVerlag, Cologne, 2004, 208 p.

1 La crise de l'Etat providence se répercute sur le secteur caritatif qui en est l'un des piliers avec 1,3 millions de salariés. L'institut IW en passe en revue les manifestations et propose des axes de réforme pour un secteur appelé à relayer largement les acteurs publics dans le domaine social. Mais les associations caritatives sont en mal de financement, car concurrencées par d'innombrables d'ONG qui multiplient elles aussi les appels aux dons. Or si les Allemands sont généreux (voir REA 70/05), ils sont encore plus soucieux de transparence. Un souci auquel répond pleinement l'instructif annuaire 2004/05 publié par le DZI, l'institution de régulation des organismes faisant appel aux dons. (ib) 